\title{
PENGEMBANGAN POTENSI PUSAT KOTA SERANG SEBAGAI WISATA HERITAGE PERKOTAAN BERBASIS MASYARAKAT
}

\author{
Arfah Sahabudin \\ Magister Pariwisata Berkelanjutan Universitas Padjadjaran \\ E-mail: arfah18001@mail.unpad.ac.id \\ Rusdin \\ Magister Pariwisata Berkelanjutan Universitas Padjadjaran \\ E-mail: rusdin@unpad.ac.id \\ M. Sapari Dwi Hadian \\ Magister Pariwisata Berkelanjutan Universitas Padjadjaran \\ E-mail: sapari@unpad.ac.id
}

\begin{abstract}
The existence of the potential for heritage tourism in center of Kota Serang is now almost eliminated and forgotten, whereas if it is managed optimally, many benefits can be generated. The purpose of the research is to reveal the potential of heritage tourism in center of Kota Serang to be developed as a tourist destination. The research method used is a qualitative method. Primary data collection through observation techniques and in-depth interviews. Secondary data through library research. Data analysis uses an interactive model, through three activities namely data reduction, data presentation, and drawing conclusions. The results of the study indicate that there is no clear strategic policy and the lack of efforts in achieving optimal utilization of potential inheritance for tourism development. The synergy of all stakeholders and decision makers is needed to run in line with the vision and mission of development. The proposed development model is community-based heritage tourism.
\end{abstract}

Keywords: heritage tourism, urban-community-based tourism, urban tourism 


\section{Pendahuluan}

Pariwisata adalah fenomena kuno yang telah berkembang sepanjang waktu; telah berubah dari sumber hiburan menjadi sumber pendapatan nasional. Pariwisata dapat membangun kembali masyarakat secara budaya, intelektual, artistik, bahkan ekonomi. Kota Serang merupakan satu dari delapan Kabupaten/Kota di provinsi Banten, yang merupakan ibu kota provinsi Banten. Sebagaimana juga Banten, Kota Serang memiliki potensi wisata yang cukup beragam, yaitu wisata alam, budaya dan buatan. Dan potensi terbesarnya adalah potensi wisata warisan / pusaka / heritage.

Wisata warisan / Heritage Tourism merupakan wisata yang memanfaatkan warisan dan peninggalan sejarah sebagai daya tarik wisatanya. (Suarmana et al., 2017). Keberadaan potensi wisata warisan di Kota Serang hampir tersingkir dan terlupakan seiring dengan adanya pembangunan kota yang terus dilakukan. Kota Serang dalam catatan sejarah, pernah menjadi pusat pemerintahan yaitu pada zaman Kolonial Belanda. Beberapa masih Nampak jejak peninggalan sejarah berupa bangunan-bangunan dengan arsitektur-arsitektur khas Eropa, serta jejak tata kota dari zaman kolonial. Kota Serang merupakan pemekaran dari Kabupaten Serang pada 10 Agustus 2007. Berdasarkan data dari Dispar Provinsi Banten dan Disparpora Kota Serang, di tahun 2018 ada 167 Wisata Sejarah dan Budaya, ada 14 Wisata Alam dan 62 Wisata Buatan.

Kondisi masyarakatnya majemuk, aksesnya mudah, ada Keraton Kesultanan Banten sebagai salah satu Kawasan Strategis Pariwisata di sebelah utara Kota Serang, sedang tumbuh perguruan tinggi dan komunitas kreatif. Serta sejak tahun 2016 sudah ada dukungan pemerintah kota terhadap konsep pariwisata berbasis masyarakat. Kondisi seperti ini seharusnya dapat membuat Kota Serang lebih unggul dibanding kabupaten/ kota lainnya; namun berdasarkan data BPS, pariwisata di Kota Serang ternyata belum dapat menjadi pemasok PAD dan belum mampu menarik banyak 
wisatawan. Kunjungan wisatawan ke Kota Serang masih menduduki rangking terakhir di provinsi Banten setelah Kota Tangerang Selatan. Berikut tabel data statistik wisatawan di Banten.

Tabel 1. Data Statistik Wisnus dan Wisman

\begin{tabular}{|c|c|c|c|c|c|c|c|c|c|}
\hline No. & Instansi & 20 & & 201 & & & & 201 & \\
\hline & & Wisnus & Wisman & Wisnus & Wisman & Wisnus & Wisman & Wisnus & Wisman \\
\hline 1 & $\begin{array}{l}\text { Kab. } \\
\text { Pandeglang }\end{array}$ & 3.146 .761 & 4.139 & 3.146 .761 & 4.139 & 5.896 .414 & 113.676 & $3,102,472$ & 2,579 \\
\hline 2 & Kab. Lebak & 54.724 & 193 & 54.724 & 193 & 350.493 & 261 & 680,102 & 357 \\
\hline 3 & Kab. Tangerang & 51.461 & 29.163 & 51.461 & 29.163 & 63.450 & 30.861 & 74,085 & 28,212 \\
\hline 4 & Kab. Serang & 9.236 .300 & 3583 & 10.63 .535 & - & 8.624 .116 & 1.347 & $8,392,828$ & 1,470 \\
\hline 5 & Kota Tangerang & 237.263 & 27.697 & 237.263 & 27.697 & 461.502 & 75.461 & $1,277,760$ & 237,996 \\
\hline 6 & Kota Cilegon & 135.867 & 35.618 & 103.667 & 39.598 & 171.261 & 59.364 & 866,772 & 46,182 \\
\hline 7 & Kota Serang & 290.119 & 6.665 & 205.423 & 490 & 309.117 & 788 & $2,208,570$ & 1,215 \\
\hline 8 & Kota Tangsel & - & - & 255.953 & 23.882 & - & - & $1,379,551$ & 8,992 \\
\hline & JUMLAH & 13.660 .818 & 108.712 & 14.505 .102 & 127.943 & 15.997 .185 & 358.221 & $17,982,140$ & 327,003 \\
\hline
\end{tabular}

Sumber: Dispar Banten (2018)

Meski demikian, kemudahan yang diperoleh akibat Revolusi Industri 4.0 dapat dimanfaatkan untuk meningkatkan produktifitas dan daya saing. Menjadi keharusan melakukan inovasi agar semua potensi alam dan budaya dapat dikemas sesuai era pariwisata 4.0 bahkan saat pandemic Covid-19 seperti saat penelitian ini disusun, dengan harapan dapat menjadi nilai tambah bagi pariwisata kota Serang dengan produk wisata yang memiliki daya pikat menarik bagi wisatawan. Upaya pengembangan yang dilakukan Pemerintah Kota Serang melalui Dinas Pariwisata Kepemudaan dan Olahraga (Disparpora) yaitu melalui diterapkannya Konsep Pariwisata Berkelanjutan dengan pendekatan Pariwisata Berbasis Masyarakat, melalui model Kampung Wisata dan dukungan terhadap Kelompok Sadar Wisata. Namun sejak diterapkannya konsep ini, masih banyak potensi wisata yang belum 
dikembangkan. Diantaranya potensi wisata warisan berupa bangunan-bangunan cagar budaya, bangunan kuno, dan bangunan yang diduga cagar budaya.

Warisan berupa bangunan bersejarah, yang berpotensi sebagai objek wisata heritage belum dibuka untuk umum sebagai sarana edukasi dan historical-tour bagi wisatawan atau pun masyarakat setempat. Bahkan sebagian peninggalan bangunanbangunan bersejarah itu kini telah mengalami perubahan bentuk dan fungsi, penurunan kualitas lingkungan, tertutup bangunan baru dan sudah rusak tidak terurus. Kunjungan wisatawan belum mengarah ke pusat kota, begitu pula Museum Negeri Banten yang persis berada di samping alun-alun masih sepi pengunjung. Keberadaan potensi wisata heritage yang dimiliki pusat kota belum dilirik wisatawan untuk disinggahi atau pun menjadi tujuan wisata. Kawasan yang dimasuksud sebagai pusat kota di Kota Serang dalam penelitian ini adalah sekitar kecamatan Serang. Yaitu berada diantara aluh-alun, Kaujon, Kaloran, Pasar Lama, Lopang hingga Cipare.

Pusat kota saat ini hanya sebuah tempat yang akan dilewati saat orang akan ke pelabuhan fery Merak untuk menyebrang ke Sumatera, atau orang yang akan menuju ke Cilegon, Anyer, Carita, Pandeglang, Tanjunglesung hingga Ujung Kulon dan Sawarna. Terlebih lagi dengan adanya akses jalan tol yang melewati Kota Serang, hampir benar-benar tidak membuat mereka masuk melalui pusat kota.
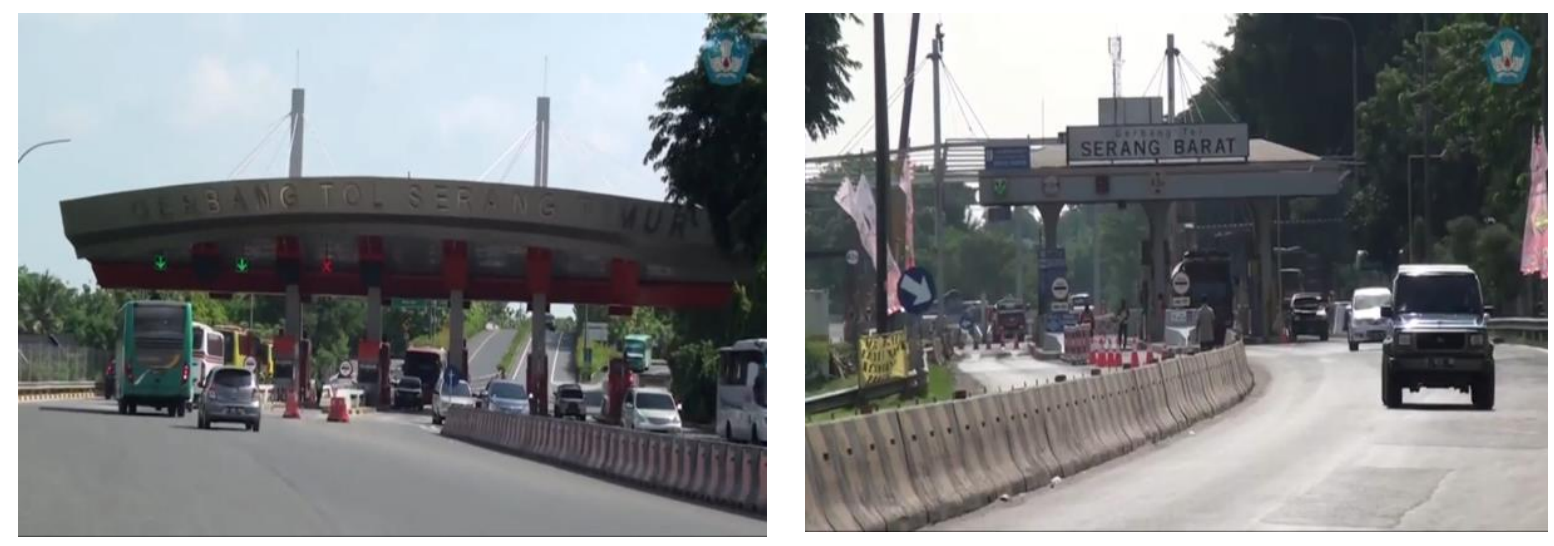
Gambar 1. Gerbang tol Serang Timur untuk masuk ke Serang (Balai Pelestarian Cagar Budaya Serang, 2015). Pelestarian Cagar Budaya Serang, 2015).

Gambar 2. Gerbang tol Serang Barat untuk masuk ke Serang (Balai

Wisatawan yang akan ke Kawasan Keraton Kesultanan Banten, yang letaknya masih di Kota Serang pun tidak memiliki alternatif lain. Meski adakalanya mereka singgah untuk berbelanja di pusat belanja "Royal" atau Pasar Rawu. Potensi wisata heritage lainnya yang tersebar di pusat kota, belum menjadi sesuatu yang dapat dilirik dan belum dapat dinikmati. Diantara sebabnya adalah bangunan-bangunan peninggalan sejarah itu meski secara defakto adalah cagar budaya, namun bila belum ada SK penetapan dari Walikota, maka statusnya masih sebagai ‘Diduga Cagar Budaya' dan sebab lain adalah belum adanya kesepakatan bersama dari pemilik / pemakai / pengelola bangunan tersebut dengan pemerintah Kota untuk dimanfaatkan sebagai objek wisata heritage atau dengan kata lain dibuka untuk kunjungan wisata. Penataan, manajemen dan pemeliharaannya tentu harus diatur dengan bijaksana.

Serangkaian unsur Urban-Heritage belum dimanfaatkan dengan maksimal, seperti alun-alun, stasiun kereta, pemukiman Pecinan tempo dulu, jejak kota (kolonial) lama, kegiatan ekonomi, museum, taman kota, mall, café dan tempat makan dll. (Kurniansah and Rosida, 2019). Begitu pula aktifitas wisata seperti city-tour, walking tour, cycling-tour di kawasan pusat kota belum nampak dilakukan oleh wisatawan dan pemandu wisata lokalnya. Alun-alun kota yang terbagi menjadi alunalun barat (biasanya digunakan untuk sholat ied, even dan upacara adat) dan alunalun timur (saat ini menjadi taman kota dan sarana olahraga). 


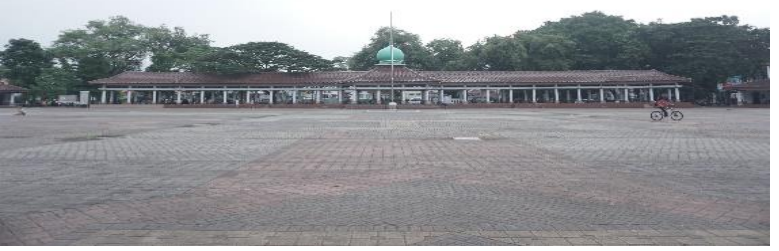

Gambar 3. Alun-alun Timur yang masih difungsikan sebagai alun-alun kota.

Sumber: peneliti (2020).

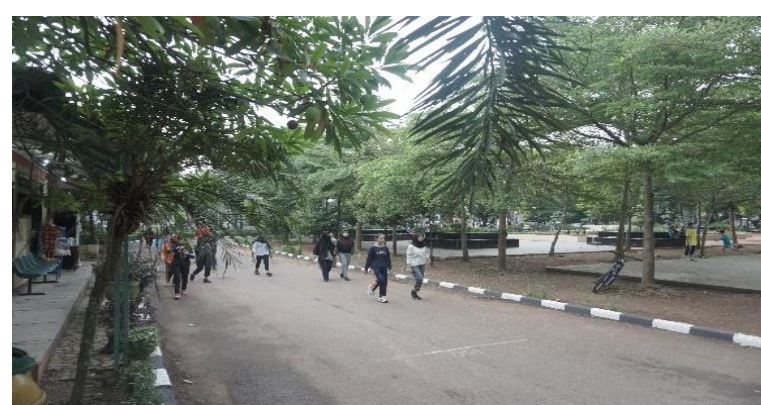

Gambar 4. Landmark Alun-alun Kota Serang di Alun-alun timur yang kini menjadi taman olahraga. Sumber: peneliti (2020).

Bertolak dari permasalahan di atas, maka dilakukanlah penelitian untuk dapat merumuskan sebuah pengembangan yang sesuai. Sedangkan fokus dalam penelitian ini yaitu tentang keberadaan heritage tourism di pusat Kota Serang dan pengembangan Pusat Kota Serang menjadi destinasi heritage tourism. Tujuan dari penelitian ini adalah untuk mengidentifikasi, menggali potensi dan menganalisis pengembangan destinasi heritage tourism di pusat Kota Serang. Hasil penelitian ini diharapkan dapat menjadi masukan serta referensi bagi pemerintah kota ataupun stakeholder's kepariwisataan dalam mengembangkan pariwisata perkotaan berbasis masyarakat di Kota Serang.

\section{Metode}

Penelitian ini merupakan penelitian kualitatif, dengan jenis data kualitatif. Data primer dikumpulkan dengan menggunakan teknik observasi di lokasi penelitian dan bertanya langsung kepada informan yang dipilih melalui formulir panduan wawancara. Data sekunder dikumpulkan dengan studi pustaka terhadap jurnaljurnal dan penelitian serupa sebelumnya juga e-book dan buku-buku terkait.

Karena pemilihan informan sangat mempengaruhi hasil dari penelitiannya, yaitu untuk mendapatkan informasi yang maksimal (Sugiyono, 2008), maka dalam penelitian ini teknik penentuan informan menggunakan teknik purposive sampling. 
Yaitu teknik penentuan informan dengan suatu pertimbangan (Sugiono, 2018). Dalam hal ini informan yang dipilih adalah dari Balai Pelestarian Cagar Budaya Banten dan Kepala Seksi Pengembangan Destinasi Wisata Dinas Pariwisata Kepemudaan dan Olahraga Kota Serang yang dianggap sangat memahami cagar budaya dan perkembangan destinasi wisata di kota Serang. Analisis data melalui model interaktif, yaitu reduksi data, display data, dan pengambilan kesimpulan yang dilakukan bersamaan. Reduksi data adalah proses pemilihan, pemusatan pada penyederhanaan, pengabstrakan, dan transformasi data "kasar" dengan merangkum data, sehingga hanya hal-hal yang pokok saja yang diambil.

Display data yaitu cara memberikan gambaran penelitian secara utuh dari data-data hasil penelitian yang sudah tersusun secara terperinci. Kemudian ditemukan pola hubungannya untuk mengambil kesimpulan. Penyajian data disusun dalam bentuk uraian sesuai dengan perolehan penelitian (Miles, 1992).

\section{Hasil Pembahasan}

\section{Konsep Pariwisata Berkelanjutan}

Kedudukan masyarakat dalam Pariwisata Berkelanjutan, adalah sebagai pemeran utama dalam membuat keputusan dan melakukan kontrol terhadap kebijakan-kebijakan yang mempengaruhi kehidupannya (Pujaastawa, 2005). Kota Serang mulai menggunakan konsep ini sejak tahun 2016. Pariwisata Berkelanjutan di Indonesia menggunakan pola Pariwisata Berbasis Masyarakat (CBT), dengan 3 model pendekatan. Yaitu Local Wisdom Tourism, Desa / Kampung Wisata dan Kewirausahaan Sosial. Di Kota Serang, CBT telah dimulai dengan dibentuknya Kampung Wisata, dikembangkannya ekonomi kreatif berbasiskan kearifan lokal dan kewirausahaan lokal meski dalam skup masih sangat kecil dan masih banyak potensi yang belum tergali. 
Pariwisata yang berkualitas mengacu pada tiga dimensi atau Triangle Quality Tourism. Pertama adalah Quality of Tourist Experience, Quality of Life para SDM dan Quality of life local people. Yaitu kualitas pengalaman berwisata, kualitas SDM pariwisata yang melayani dan kualitas masyarakat di sekitar objek wisata (Bagus, 2020).

\section{Pariwisata Perkotaan}

Pariwisata perkotaan berbeda dengan pariwisata pada umumnya. Pariwisata perkotaan daya tarik wisatanya bukan disiapkan khusus untuk mereka yang sengaja datang berwisata, tapi menggunakan fasilitas yang sudah ada di kota sebagai daya tarik wisata (Adriani, 2011). Kebanyakan orang mengunjungi kota untuk lebih dari satu alasan. Bisa jadi untuk berbisnis, belanja, mengunjungi keluarga, lalu Sebagian dari mereka menyempatkan diri untuk mengunjungi museum atau galeri seni, menyaksikan pertunjukan suatu even dan lain-lain.

\section{Pariwisata Warisan/ Pusaka (Heritage Tourism).}

Saat ini wisata warisan sejarah dan budaya (heritage tourism) merupakan sektor yang paling pesat perkembangannya. Dan Heritage Tourism saat ini merupakan industri pariwisata terbesar di dunia (Ardika, 2015). Di Indonesia, Cagar Budaya di atur dalam Undang-Undang Republik Indonesia Nomor 11 Tahun 2010.

Menurut UU no. 11/2010, Cagar Budaya adalah warisan budaya bersifat kebendaan yang berupa benda cagar budaya, bangunan cagar budaya, struktur 
cagarbudaya, situs cagarbudaya, dan kawasan cagar budaya yang berada di darat dan atau di air yang perlu dilestarikan keberadaannya karena memiliki nilai penting bagi sejarah, ilmu pengetahuan, pendidikan, agama, dan kebudayaan melalui suatu proses penetapan. Menurut UU no. 11/2010, pengembangan cagar budaya adalah peningkatan potensi nilai, informasi, dan promosi cagar budaya serta pemanfaatannya melalui sebuah penelitian, revitalisasi, dan adaptasi secara berkelanjutan serta tidak bertentangan dengan tujuan pelestarian.

Pengembangan Cagar Budaya harus memperhatikan prinsip kemanfaatan, keamanan, keterawatan, keaslian, dan nilai-nilai yang melekat padanya. Siapapun dapat melakukan pengembangan cagar budaya setelah memperoleh izin diantaranya dari Pemerintah atau Pemerintah Daerah, atau dari pemilik dan/atau yang menguasai Cagar Budaya. Kemudian diarahkan untuk memacu pengembangan ekonomi yang hasilnya dapat digunakan untuk pemeliharaan cagar budaya itu dan peningkatan kesejahteraan masyarakat di sekitarnya. Lokasi arkeologi yang menghasilkan wisata warisan, adalah salah satu komponen terpenting dari pariwisata berkelanjutan. Maka melestarikan warisan kota dan arsitekturnya adalah hal yang amat penting bagi pariwisata berkelanjutan (Hmood et al., 2018). Berikut gambar-gambar sebagian gedung-gedung bersejarah di pusat Kota Serang.

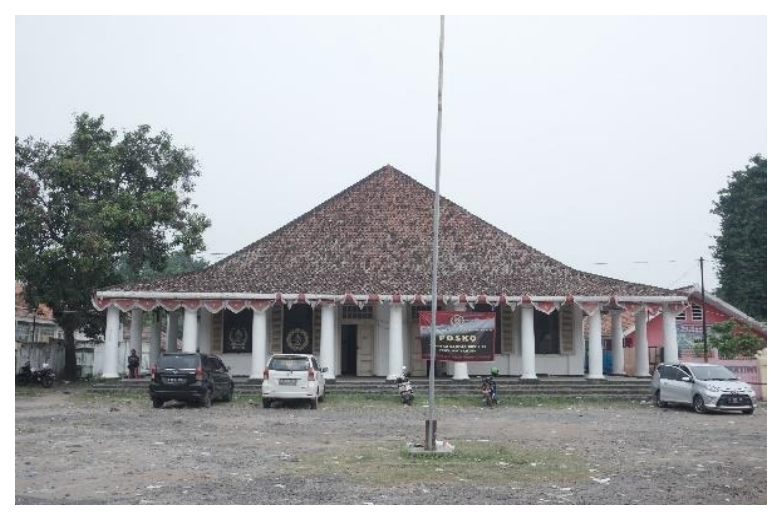

Gambar 5. Gedung Joeang 45. Pernah menjadi markas Kampetay kemudian BKR pimpinan Samaun.

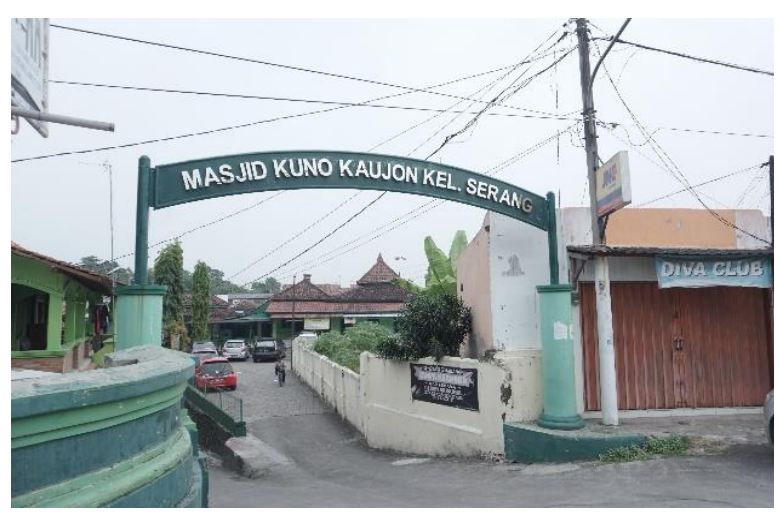

Gambar 6. Mesjid Kuno Kaujon, yang diperkirakan ada sejak sebelum 1875. Sumber: Peneliti (2020). 
Sumber: peneliti (2020).

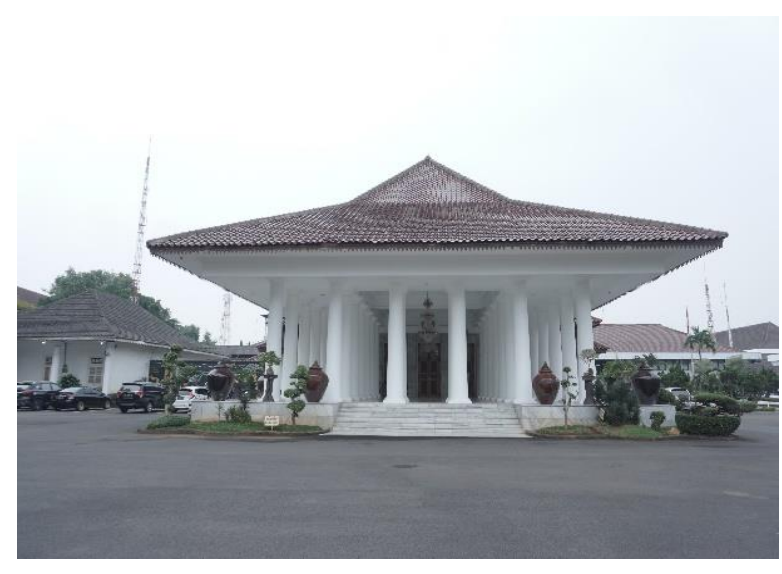

Gambar 7. Gedung Pendopo Bupati Kabupaten Serang Sumber: Peneliti (2020).

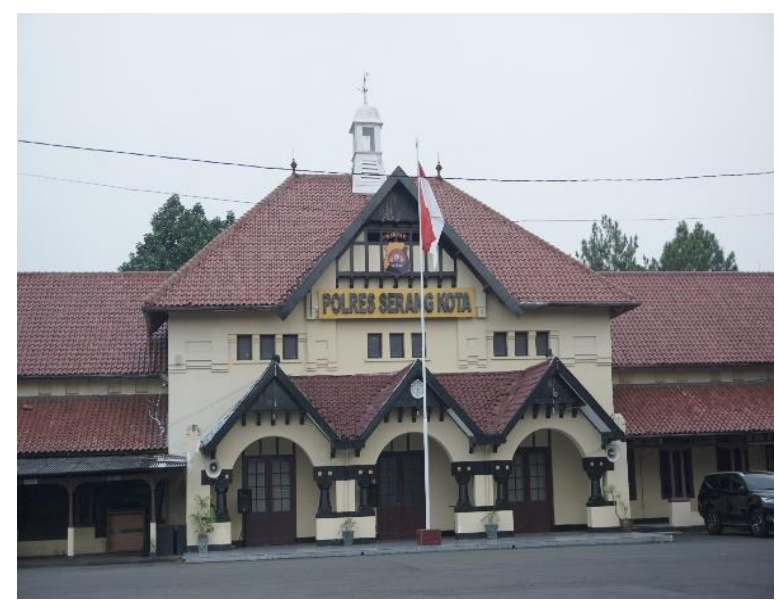

Gambar 9. Gedung ex OSVIA yang kini menjadi Kantor Polres Serang.

Sumber: Peneliti (2020).

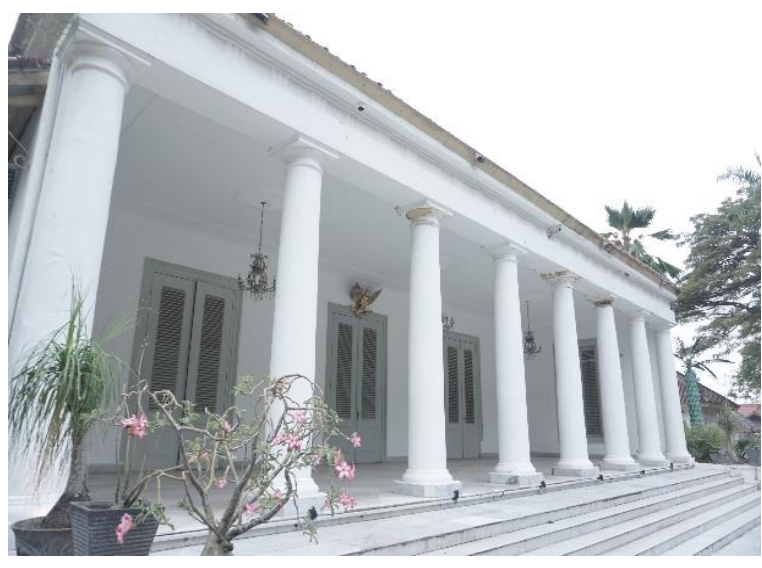

Gambar 8. Gedung ex Kersidenan Banten / ex Musium Negeri Banten. Sekarang menjadi Gedung Negara. Sumber: Peneliti (2020).

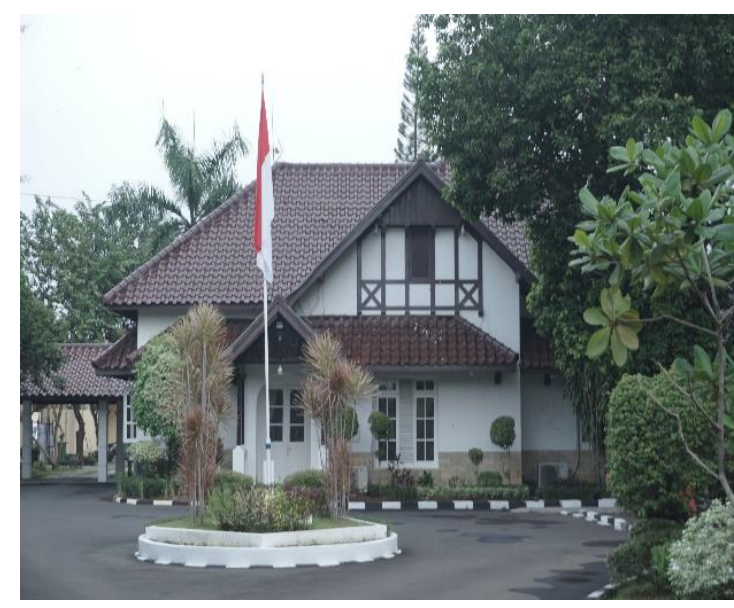

Gambar 10. Bangunan yang saat ini dimanfaatkan sebagai rumah dinas Kapolda Banten. Sumber: Peneliti (2020). 


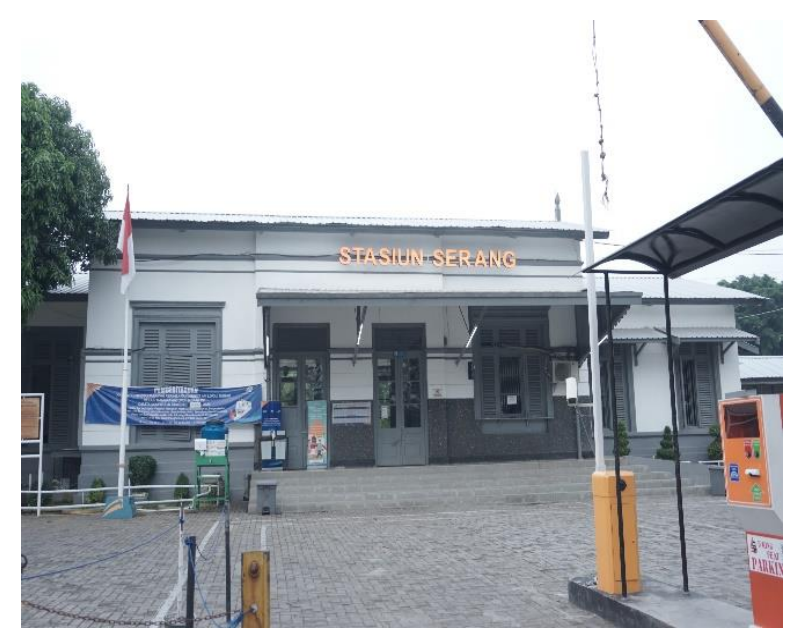

Gambar 11. Stasiun Kereta Serang. Sumber: Peneliti (2020).

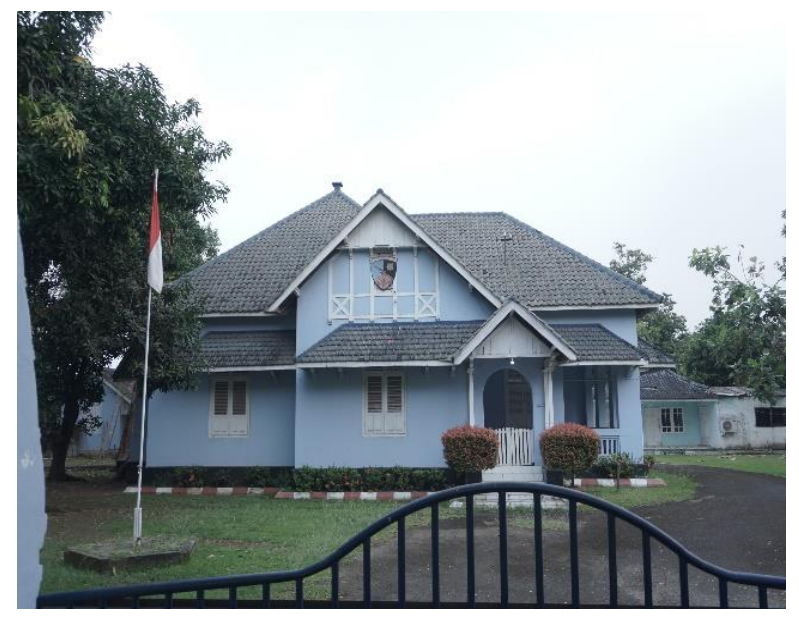

Gambar 13. Rumah Dinas AU Gorda. Sumber: Peneliti (2020).

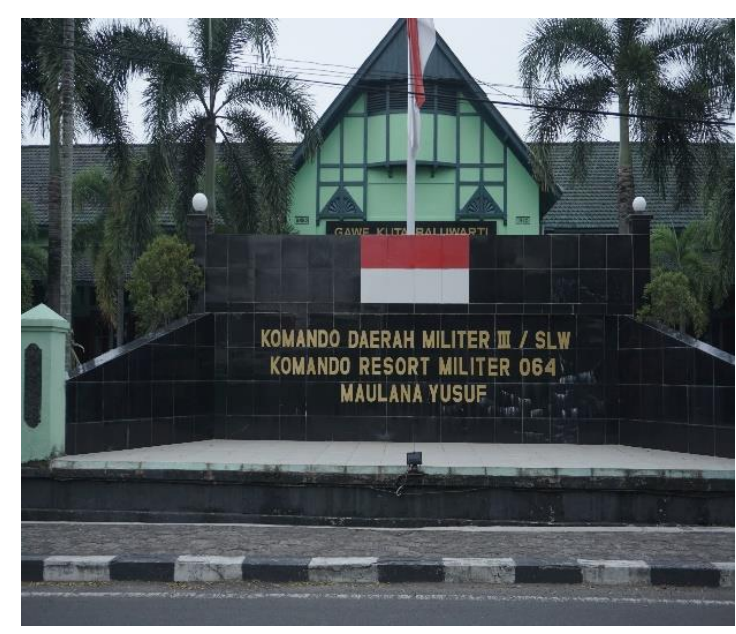

Gambar 12. Makorem 064 Maulana Yusuf.

Sumber: Peneliti (2020).

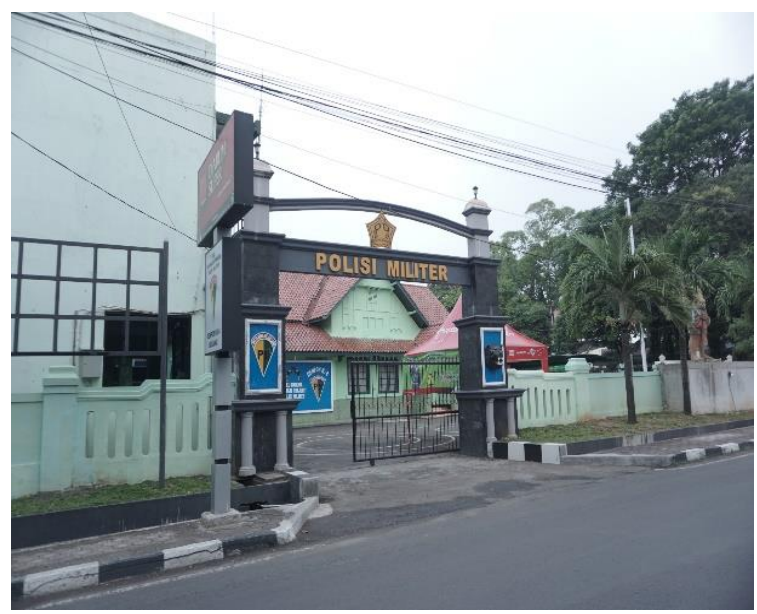

Gambar 14. Gedung Denpom.

Sumber: Peneliti (2020). 


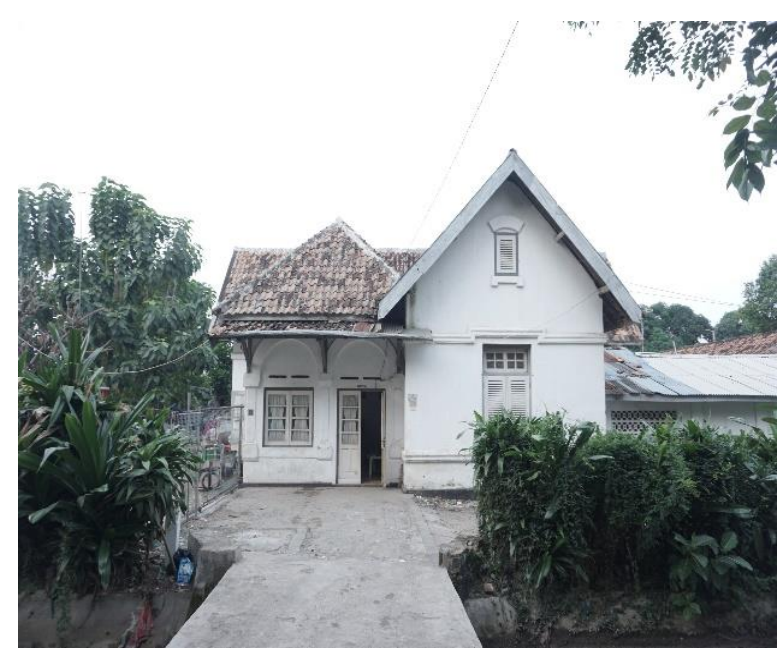

Gambar 15. Rumah kuno warga sekitar stasiun.

Sumber: Peneliti (2020).

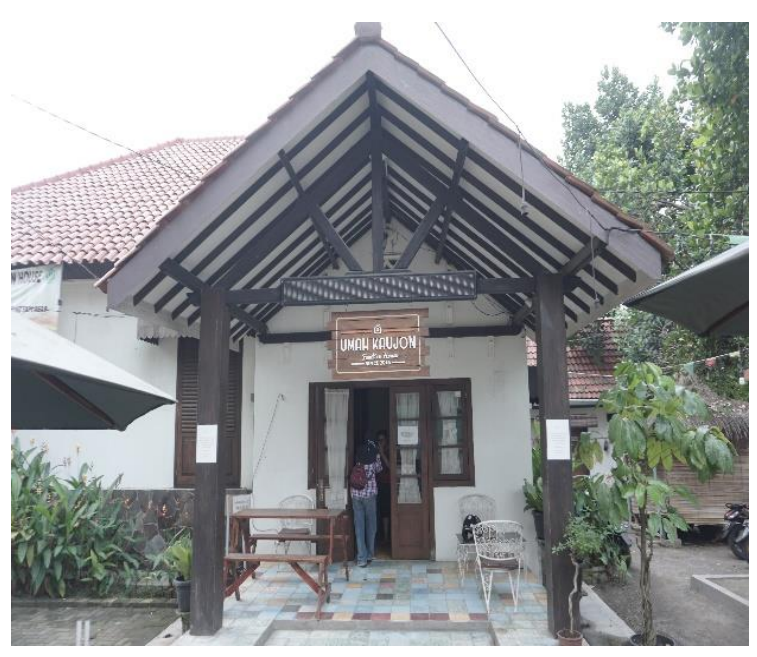

Gambar 16. Rumah kuno warga sekitar Kaujon.

Sumber: Peneliti (2020).

Pariwisata berkelanjutan yang diterapkan di Kota Serang merupakan aktivitas ekonomi penting, karena jika dikembangkan secara tepat, dapat mengatasi sejumlah tantangan pembangunan, termasuk pengurangan kemiskinan, pengembangan ekonomi lokal, perdamaian, keselarasan masyarakat, dan manajemen sumber daya alam budaya dan lingkungan yang berkesinambungan. Melalui Pariwisata berkelanjutan masyarakat didorong untuk mempunyai kemandirian mengelola potensi daerahnya, menciptakan produk wisata yang menarik bagi pengujung dan wisatawan dengan tetap memperhatikan keberlangsungan dan kelestarian lingkungan alam, sosial dan warisan budaya.

Dalam menjalankan Konsep Pariwisata berkelanjutan, oleh Disparpora, masyarakat diberi pelatihan yang sekiranya dapat mendukung agar ekonomi tumbuh; dan berdampak pada kesejahteraan masyarakat; dalam membangun pariwisata tidak merubah struktur alam dan warisan sejarah budaya, melindungi 
sumber daya alam dan sejarah; serta mendorong kebudayaan masyarakat tumbuh. Pelatihan dan workshop yang diadakan untuk masyarakat khususnya Pokdarwis dan warga Kampung Wisata, bertujuan agar masyarakat sebagai tuan rumah dapat memberikan pelayanan yang layak dan dapat memberikan kepuasan kepada wisatawan yang berkunjung. Hal inilah yang diharapkan dalam konsep Pariwisata Berkelanjutan

Pengembangan yang sedang dilakukan oleh masing-masing Pokdarwis di destinasi wisatanya; diharapkan mampu menjamin keberkelanjutan lingkungan, sosial budaya, ekonomi serta dapat menyesuaikan dan memanfaatkan teknologi dengan layak untuk diterapkan. Dengan kata lain, dalam pengembangan pariwisata di Kota Serang, sudah mulai dilakukan usaha kearah pelestarian dan perlindungan terhadap sosial-budaya dan lingkungan hidup. Juga memberikan pendidikan dan pelatihan tentang kepariwisataan kepada masyarakat lokal dan mengikutsertakan mereka dalam proses perencanaan, pengembangan, pelestarian, serta penilaian terhadap pengembangan pariwisata.

Penggunaan konsep pembatasan daya tampung (carrying capacity), saat ini belum diterapkan. Yaitu membatasi kunjungan wisatawan sesuai dengan kapasitas yang dapat ditampung oleh atraksi/ objek sehingga tidak menimbulkan dampak yang negatif terhadap lingkungan dan masyarakat lokal. Begitu pula dengan usaha untuk memberikan informasi dan sosialisasi kepada wisatawan dan masyarakat lokal mengenai pentingnya menjaga dan melestarikan warisan budaya; masih perlu ditingkatkan

Demikian juga terhadap penelitian secara berkala untuk evaluasi perkembangan dan penyimpangan terkait penerapan konsep pengembangan pariwisata berkelanjutan, sangat perlu dilakukan. Agar tujuan awal dari penerapan konsep ini dapat terus terlaksana dan mendapatkan hasil baik bagi masyarakat bahkan terhadap pendapatan daerah. 


\section{Konsep Pemberdayaan Masyarakat dalam Community Based Tourism (CBT)}

Pariwisata Berkelanjutan di Indonesia seperti disinggung di atas, menggunakan pola Community Based Tourism (CBT) diantaranya menggunakan 3 model pendekatan yaitu pengembangan local wisdom tourism, pengembangan desa / kampung wisata dan pengembangan kewirausahaan sosial, begitu pula saat ini sedang dikembangkan di Kota Serang. Dalam rangka pemberdayaan masyarakat dan dalam rangka menjalankan konsep pariwisata berkelanjutan, di sekitar destinasi di 6 Kecamatan sudah dibentuk Kelompok Sadar Wisata (Pokdarwis) yang telah merintis Kampung Wisata. Dengan Pokdarwis, diharapankan masyarakat dapat berperan lebih aktif mewujudkan Sapta Pesona dan menumbuhkan lingkungan yang kondusif untuk pertumbuhan dan perkembangan kepariwisataan. Berdaya menyelesaikan masalah ekonomi dan melestarikan budayanya, berbudaya dalam berkehidupannya.

Program ini adalah bertujuan mewujudkan idealisme ekonomi berbasis kerakyatan. Yang diimplementasikan dengan memberdayakan seluruh elemen di setiap kelurahan / kampung untuk menggerakkan pariwisata. Sehingga dalam membangun akomodasi misalnya, tidak diperlukan pembangunan akomodasi baru di kampung wisata dengan modal yang besar. Karena rumah-rumah warga dapat dialihfungsikan menjadi homestay. Potensi kearifan lokal diangkat sebagai daya tarik wisatanya. Termasuk tatacara berkehidupan mereka selama ini dan tatacara tradisional bermasyarakat yang sudah mereka peroleh sebagai warisan leluhur. Kuliner dan cara mereka mengolah dan mendapatkan bahan makanannya. Termasuk budaya peribadatannya.

Selain menjadi daya tarik bagi wisatawan, pariwisata berbasis masyarakat dapat memunculkan rasa bangga bagi masyarakat lokal karena mereka tidak hanya menjadi penonton melainkan telah berpartisipasi di industri pariwisata di tempatnya (Bagus, 2020). Begitu pula dengan kreasi kerajinan dan kuliner yang dimiliki 
masyarakat, dapat menjadi daya tarik khas dan dapat menjadi sumber penghasilan melalui penjualan oleholeh, wisata kuliner, wisata gastronomi. Hal positif lainnya dari pariwisata berbasis masyarakat adalah tidak adanya eksploitasi lingkungan untuk kepentingan pariwisata. Selama ini pariwisata dianggap sebagai penyebab kerusakan ekologi karena kegiatan pariwisata memerlukan pembukaan lahan secara masif.

Melalui konsep pariwisata berkelanjutan ini, masyarakat sebagai pelaku pariwisata hanya perlu mengelola potensi wisata yang ada secara bijak guna mewujudkan prinsip keberlanjutan pada aspek lingkungan hidup. Sebagai contoh, di Rintisan Kampung Wisata Pancer yang digerakkan oleh Kelompok sadar wisata Kiamuk yang berada di sebelah utara dari pusat Kota Serang, di Kecamatan Kasemen Kelurahan Banten; masyarakat bersama Kelompok Sadar Wisata yang mereka sebut Pokdarwis Kiamuk, melakukan kegiatan rutin penanaman mangrove yang sekaligus menjadi salah satu atraksi dan daya tarik ekowisata dan wisata edukasi di sana.

Daya tarik alam berupa pesisir Teluk Banten, pelabuhan tua sejak zaman sebelum Kesultanan Banten lahir hingga menjadi pelabuhan iternasional di zaman Kesultanan, merupakan daya tarik wisata heritage yang amat potensial, kemudian kehidupan perkampungan nelayan, pemukiman suku Bugis, bekas pemukiman warga Tionghowa di zaman Kesultanan, dan beragam suku budaya sebagaimana layaknya pelabuhan yang menjadi tempat transit hingga bermukimnya beragam suku budaya di sana adalah aset wisata yang potensial untuk dikembangkan. Posisi yang strategis dan menjadi bufferzone Kawasan Kesultanan Banten dan lain sebagainya adalah hal-hal yang menguntungkan bagi masyarakat di sekitarnya untuk dimanfaatkan sebaik-baiknya dalam kepariwisataan dan pengembangan ekonomi kerakyatan. Begitu pula dengan Rintisan Kampung Wisata Situ Ciwaka, yang memiliki danau buatan. Dan Rintisan Kampung Wisata Selfie Pipitan Kreatif di 
Kecamatan Walantaka. Yang memiliki karya-karya kreatif handmade dan kuliner khas daerah.

Dari 10 Pokdarwis yang sudah disahkan melalui SK Kepala Disparpora Kota Serang, 5 Pokdarwis telah merintis Kampung Wisata. Sedangkan 5 lainnya sedang dalam tahap menggali potensi dan pemantapan sadar wisata. Salah satu dari 5 Pokdarwis itu adalah yang berada di pusat kota. Pokdarwis ini belum terlihat aktif melakukan gerakan sadar wisata ataupun kegiatan wisata lainnya. Oleh karena itu Sadar wisata masyarakat di pusat kota masih kurang, padahal bila ditilik lokasinya, Pokdarwis ini berada di lokasi sentral Kota yang potensi heritagenya dan potensi pariwisata perkotaannya dominan. Yaitu berada di sekitar Alun-alun Kota Serang. Artinya Konsep Pariwisata Berbasis Masyarakat di pusat Kota Serang belum terlaksana.

Selain dari belum aktifnya Pokdarwis di Kawasan pusat kota ini sehingga sadar wisata belum diperoleh masyarakat, sumber daya wisata yang dimiliki berupa potensi wisata heritage pun belum dimanfaatkan maksimal. Perlu Kerjasama, kesatuan visi misi dan dukungan semua warga masyarakat, pengelola / pemilik gedung, komunitas- komunitas yang berada di sekitar lokasi, untuk memanfaatkan potensi yang ada sebagai satu kesatuan produk wisata heritage pusat kota. Terutama sekali adalah dukungan dan kerjasama dari Pemerintah Kota Serang.

Pendekatan pariwisata berbasis masyarakat atau community-based tourism (CBT) adalah pendekatan pembangunan pariwisata dengan perencanaan yang partisipatif. Artinya pembangunannya melibatkan masyarakat lokal dengan memberi kesempatan dalam mengelola dan membangun pariwisata, baik secara langsung maupun tidak langsung terkait dengan industri atau usaha pariwisata, dan melakukan distribusi keuntungan merata. Pendekatan pariwisata seperti ini belum merata diterapkan di semua potensi destinasi wisata. Termasuk di pusat kota. Karena 
kepahaman masyarakat terhadap pentingnya potensi ini dan hubungannya dengan pariwisata serta kebermanfaatannya terhadap ekonomi masyarakat masih kurang, maka konsep pembangunan pariwisata berkelanjutan di pusat kota belum terlihat memberikan hasil.

\section{Pengembangan}

Pengembangan potensi pariwisata mengandung makna upaya dalam meningkatkan sumber daya yang dimiliki sebuah destinasi wisata dengan melakukan pembangunan baik berupa unsur-unsur fisik hingga non fisik dari sistem pariwisata sehingga dapat meningkatkan produktivitas dan nilai jual. (Badarab et al., 2017). Sebagai sebuah kota yang sedang membangun, dengan berbagai masalah krusial, termasuk keterbatasan anggaran, maka langkah yang perlu diambil untuk pengembangan pariwisata perkotaan adalah, pendampingan kepada Pokdarwis dan masyarakat lokal, merencanakan perbaikan produk yang ada, peningkatan manfaat potensi wisata perkotaan; yaitu melalui pengembangan potensi wisata yang akan dijadikan sebagai destinasi wisata heritage perkotaan dan unsur-unsur destinasi lainnya seperti amenitas, kelembagaan dan aksesibilitasnya.

\section{Potensi Pusat Kota Serang Sebagai Heritage Tourism}

Kota Serang memiliki aset wisata perkotaan (urban tourism) yang cukup banyak. Hampir mirip dengan kota-kota lain di Indonesia seperti Jakarta dan Semarang yang memiliki warisan budaya berupa arsitektur kolonial. Peninggalan berupa bangunan-bangunan bersejarah, seperti bekas Kersidenan Banten, bangunan bekas sekolah zaman Belanda (OSVIA, Opleidings School Voor Inlandsche Ambtenaren), kemudian stasiun kereta api, Gelanggang Olahraga, Stadion, Alun-alun kota, Pecinan dan peninggalan ritual-ritual budaya keagamaan yang belum terekspos; merupakan aset dan sumber daya pariwisata yang amat potensial. 
Berikut berhasil disusun daftar Potensi Wisata Perkotaan Di Pusat Kota Serang dari hasil observasi dan studi Pustaka.

Tabel 2. Potensi Wisata Perkotaan Di Pusat Kota Serang.

\begin{tabular}{|c|c|c|}
\hline Culture-Heritage & Alam & Buatan / Alternatif \\
\hline Gedung Joeang 45 & Sungai Cibanten & Gastronomi \\
\hline Alun-alun & & Kuliner \\
\hline Keresidenan Banten & & Kampung Tematik \\
\hline Kantor Bupati dan Mess Staf Ahli & & Urban Tourism Even \\
\hline Kantor Dipenda Kabupaten Serang & & City tour \\
\hline Kantor POLRES Serang & & Cycling tour \\
\hline Rumah Dinas Kapolda Banten & & Virtual tour \\
\hline Rumah Dinas Wakapolda Banten & & GOR \\
\hline Rumah Dinas Wakapolres Serang & & Stadion \\
\hline Rumah Dinas TNI AU Corda & & Mall of Serang \\
\hline Masjid Kuno Kaujon & & Pusat Pemkot \\
\hline Makorem 064 Maulana Yusuf & & Pusat Oleh-oleh \\
\hline Kantor PM Serang & & Wisata Belanja Royal \\
\hline Mess Perwisara AD & & Sentra Kelapa Muda \\
\hline Rumah Dinas Komandan Denpom & & MICE \\
\hline Rumah Jabatan Danrem & & Taman Seni Budaya \\
\hline Rumah Tahanan Kelas IIB Serang & & Ramayana Mall \\
\hline Rumah Dinas Kepala Rutan & & Kampung Kuno \\
\hline Jembatan Kaujon & & Kota Kolonial \\
\hline \multicolumn{3}{|l|}{ Stasiun Kereta Api Serang } \\
\hline \multicolumn{3}{|l|}{ Rumah-rumah Kuno di Kaujon } \\
\hline \multicolumn{3}{|l|}{$\begin{array}{l}\text { Rumah-rumah Kuno di } \\
\text { Pegantungan }\end{array}$} \\
\hline Kesenian dan silat & & \\
\hline
\end{tabular}




\begin{tabular}{|l|l|l|}
\hline Tradisi Panjang Mulud & & \\
\hline Kue dan Makanan khas & & \\
\hline
\end{tabular}

Sumber : (Kemendikbud dan BPCB, 2016) dan olahan peneliti 2020

Pada tahu1820, Serang telah menjadi wilayah yang paling lengkap untuk disebut kota karena telah memiliki pusat pemerintahan, alun-alun sebagai meeting point, pasar, sekolah, rumah sakit, rumah ibadah dan penjara. Kemudian tumbuhlah perkampungan-perkampungan seperti pecinan, pusat perdagangan dan tempat ibadah, lalu stasiun kereta api di Karangantu dan Cilame. Hingga pembangunan 1000 $\mathrm{Km}$ jalan raya dari Anyer-Panarukan yang melalui Serang. Jadilah Serang sebagai kota terencana denganciri khas kota yang dibangun oleh Kolonial (hasil wawancara dengan informan).

Bila dikaitkan dengan Visi Misi Walikota dan Wakil Walikota Serang Periode 2018 - 2023, Pemerintah Kota sudah mendukung pelestarian budaya. Visinya berbunyi "Terwujudnya Kota Peradaban yang Berdaya dan Berbudaya". Sedangkan Misinya; "Menguatkan Peradaban Berbasis Nilai-nilai Kemanusiaan, Meningkatkan Sarana Prasarana Daerah yang Berwawasan Lingkungan, Meningkatkan Perekonomian Daerah dan Pemberdayaan Masyarakat yang Berdaya Saing dan Meningkatkan Tata Kelola Pemerintahan yang Baik" (Walikota Serang Provinsi Banten, 2015).

Misi ketiga jelas merupakan bentuk kepedulian dan dukungan pemerintah terhadap masyarakat. Secara keseluruhan visi misi ini menunjukkan perhatian dan kepedulian pemerintah kota mulai mengarah kepada pengembangan kepariwisataan dan pelestarian budaya dan pemberdayaan masyarakat. Biaya pemeliharaan aset-aset heritage cukup besar. Melibatkan masyarakat dapat membatu mengatasi masalah ini. 
Karena masyarakat akan ikut memelihara bila dilibatkan dalam pemanfaatan dan pelestariannya. Masyarakat pun dapat manfaatnya.

\section{Masyarakat harus diajak sejak awal dalam rencana pengembangan pariwisata heritagenya}

Selain faktor anggaran, faktor-faktor yang diduga penghambat pengembangan pariwisata perkotaan berbasis masyarakat adalah infrastruktur pendukung dan sarana prasarana pariwisata masih kurang, tenaga terampil dan pengetahuan pariwisata di dinas / masyarakat masih kurang, respon warga terhadap program bermacam-macam, sadar wisata masih kurang, masih ada konflik lahan di beberapa lokasi, pariwisata belum dilihat sebagai sektor unggulan dan belum menjadi prioritas pembangunan, promosi pariwisata di kota Serang belum memadai, warung / toko / bangunan sepanjang jalan utama tidak tertata rapi bahkan menutup bangunan bernilai heritage, antar stakeholder/ lembaga pariwisata belum saling berintegrasi.

Istilah Pariwisata seolah bagian terpisah dari kehidupan bermasyarakat. Padahal Saptapesona merupakan bagian dari berkehidupan. Peluang macet akan tinggi karena tidak ada kantung parkir. Sampah akan berserakan karena pengelolaan kurang baik dan kurang terencana. Masuknya investor tanpa pertimbangan lingkungan dan pelestarian budaya heritage juga akan membuat pengembangan tidak maksimal tapi justru menimbulkan masalah baru.

\section{Simpulan dan Saran}

\section{Simpulan}

Karena potensi wisata perkotaan (urban tourism) di Kota Serang memang sudah cukup lengkap, amenitas cukup memadai, aksesnya pun mudah, ditambah dengan potensi wisata heritagenya terutama di pusat kota, maka sangat potensial apabila dilakukan pengembangan Urban Heritage Tourism di pusatkotanya. Tentu saja sesuai dengan model pengembangan pariwisata yang diterapkan di kota Serang 
yaitu Pariwisata Berkelanjutan dengan pendekatan CBT maka konsep pengembangan pariwisata pusat kota di Kota Serang adalah Community-based Urban Heritage Tourism.

Konsep Urban Tourism Berkelanjutan harus memastikan keseimbangan dari manfaat pariwisata sekarang dengan peluang untuk masa yang akan datang. Pengembangan pariwisata perkotaan harus berkontribusi pada kesejahteraan masyarakat dan mereka yang secara langsung terlibat di industri pariwisata lokal dan kepuasan pengalaman wisatawan. Konsep Urban Heritage Tourism Berbasis Masyarakat, harus menyeimbangkan antara kebutuhan masyarakat, sumber daya yang tersedia, upaya pemerintah dan stakeholder's dan perencanaan kota, sekaligus upaya pelestarian lingkungan dan budaya. Dengan tentu saja tetap memperhatikan Kota Serang adalah kota dengan masyarakat yang religius.

Agar potensi yang ada dapat dikembangkan dan memiliki nilai tambah yang menjual yaitu mampu memberikan kualitas pengalaman kepada wisatawan sekaligus dapat meningkatkan kualitas hidup dan jaminan kelangsungan sumber daya alam dan budaya lokal, pemerintah kota dan segenap stakeholder's harus lebih serius melakukan upaya pengembangan pariwisata perkotaan berbasis masyarakat. Unsur atraksi sudah ada tinggal dibenahi dan dibantu dengan regulasi pemanfaatannya. Unsur amenitas dan aksesbilitasnya sudah cukup memadai. Aktifitas wisata heritage yang dapat dilakukan yaitu walking tour / city tour / cycling tour, napak tilas kota lama (kolonial), historical tourism, educational tourism dan even-even budaya. Serta kegiatan ekonomi kreatif berbasis kearifan lokal dan pemberdayaan masyarakat.

Selanjutnya menyikapi situasi pandemic Covid-19 seperti saat penelitian ini dilakukan, virtual tour adalah solusi berwisata dari rumah yang dapat dilakukan. Tentunya persiapan aktual destinasi harus sudah terlebih dahulu dilakukan, objek wisatanya harus sudah siap di kunjungi meskipun secara online.

\section{Saran}


Program pemberdayaan masyarakat melalui pariwisata, dapat disinergikan dengan program-program lain dari setiap Organisasi Perangkat Daerah. Agar pergerakannya lebih kuat dan serempak. Perlu kesamaan visi misi pembangungan dari setiap OPD. Sehingga program yang dijalankan dapat saling mendukung. Meskipun kemandirian masyarakat adalah tujuan program ini, program CBT di Kota Serang masih sangat perlu pendampingan dari pemerintah dan seluruh unsur pentahelix.

Dalam merencanakan dan menyiapkan sebuah atraksi wisata dalam suatu paket wisata, sebaiknya dipastikan status benda-benda cagar budaya / benda-benda di duga cagar budaya itu telah memiliki status dan izin / dibuka untuk umum. Oleh itu amat diperlukan sebuah ketetapan dari Pemerintah Kota tentang status bangunan dan benda-benda heritage. Agar dapat dibuka dan dimanfaatkan untuk keperluan wisata heritage perkotaan berbasis masyarakat,

\section{Ucapan Terima Kasih}

Terima kasih kepada Bapak dan Ibu dari Dinas Pariwisata Kepemudaan dan Olahrga (Disparpora Kota Serang) dan Bapak Juliadi dari Balai Pelestarian Cagar Budaya (BPCB) Banten. Serta kepada semua sahabat yang telah membantu proses penelitian dan penyusunan artikel ini.

\section{Daftar Pustaka}

Adriani, Y., 2011. Pariwisata Perkotaan: Teori \& Konsep [WWW Document]. URL http://tentangpariwisata.blogspot.com/2011/01/pariwisata-perkotaan-teoridan-konsep.html

Ardika, I.W., 2015. Warisan Budaya Perspektif Masa Kini. Denpasar. Udayana University Press, Denpasar.

Badarab, F., Trihayuningtyas, E., Suryadana, M.L., 2017. Strategi Pengembangan Destinasi Pariwisata di Kepulauan Togean Provinsi Sulawesi Tengah. J. Tour. Hosp. Essentials J. 7. 
Bagus, R.U.I.G., 2020. Pariwisata Mesti Kedepankan Konsep Berkelanjutan dan Kualitas [WWW Document]. https://www.researchgate.net. URL https://www.researchgate.net/publication/339376555_Pariwisata_Mesti_Kede pankan_Konsep_Berkelanjutan_dan_Kualitas/stats

Balai Pelestarian Cagar Budaya Serang, 2015. Potensi Cagar Budaya di Kota Serang [WWW Document]. URL https://www.youtube.com/watch?v=fI_TPyYJljU (accessed 6.12.20).

Hmood, K., Jumaily, H., Melnik, V., 2018. Urban architectural heritage and sustainable tourism. WIT Trans. Ecol. Environ. 227, 209-220.

Kemendikbud dan BPCB, 2016. Database Cagar Budaya di Kota Serang. Kota SeraNG.

Kurniansah, R., Rosida, L., 2019. STRATEGI PENGEMBANGAN PARIWISATA PERKOTAAN (URBAN TOURISM) KOTA MATARAM PROVINSI NUSA TENGGARA BARAT. MEDIA BINA Ilm. 14, 2061.

Miles, M.B. dan A.M.H., 1992. Analisis Data Kualitatif: Buku Sumber tentang MetodeMetode Baru. UI Press, Jakarta.

Pujaastawa, I.B.G. dkk, 2005. Pariwisata Terpadu Alternatif Model Pengembangan Pariwisata Bali Tengah. Universitas Uidayana., Denpasar.

Suarmana, I.W.R., Ardika, I.W., Darma Putra, I.N., 2017. PENGEMBANGAN PUSAT KOTA DENPASAR SEBAGAI 'HERITAGE TOURISM.' J. Master Pariwisata.

Sugiono, R., 2018. METODOLOGI PENELITIAN SOSIAL. Suatu Pendekatan Teori dan Praktis. Alfabeta, Bandung.

Sugiyono, 2008. Metode Penelitian Kuantitatif, Kualitatif dan R\&D. Alfabeta, Bandung.

Walikota Serang Provinsi Banten, 2015. PERDA Kota Serang No. 14 / 2014. Indonesia.

\section{Profil Penulis}

Arfah Sahabudin, S.Kom., lahir di Polmas (Polewali Mamasa) Sulawesi Barat 17 September 1972. Adalah seorang pelaku wisata (Pokdarwis Kiamuk, Kampung Wisata Pancer, Himpunan Pramuwisata Indonesia, Catering \& Jasa Boga, kerajinan daur ulang, aneka oleh-oleh khas Banten, dan Coffeeshop). Mendapatkan gelar S1 dari Universitas Gunadarma Depok jurasan Manajemen Informatika pada tahun 1995. Saat ini sedang menyusun tesis di Magister Pariwisata UNPAD, Program Studi Pariwisata Berkelanjutan. 
Drs. Rusdin, M.Si. (www.rusdintahir.com), sejak 1996 bekerja sebagai Dosen dan Peneliti di Departemen Administrasi Bisnis dan pengampu s ubjek Organisasi dan Manajemen, Strategi Sumber Daya Manusia, Pengukuran Kinerja dan Strategi Kompensasi, Perilaku Organisasi, Filsafat Ilmu Pengetahuan, dan Metodologi Penelitian di Sekolah Pascasarjana Program Studi Pariwisata Berkelanjutan, Master dan Program Studi Doktor. Program Pascasarjana Ilmu Administrasi Bisnis di Universitas Padjadjadjaran. Meraih Sarjana \& Pascasarjana: Administrasi Bisnis, Universitas Pendidikan Indonesia (1992); Gelar Master (2000) Gelar Doktor (2013) di Universitas Padjadjaran.

Dr. M. Sapari Dwi Hadian, ST., M.T. seorang peneliti senior Water Center di Universitas Padjadjaran, Bandung, Indonesia. Memiliki 19 tahun pengalaman penelitian dan konsultasi tentang Geologi dan Hidrogeologi Lingkungan, Technopark Sains, Geopark, Bahaya Geologi, pariwisata lingkungan dan masalah pelestarian. Dia juga seorang profesor di Departemen Geologi, Universitas Padjadjaran (Unpad), Bandung, Indonesia. Sejak 2012, ia telah menjadi anggota Science Techno park di Unpad, dan 2015 World Technopolis Association (WTA) Korea. 